\title{
Dakwah Strategiesand Challenges for the People With Disabilities (PWD) in Singapore
}

\author{
M B Tokyan ${ }^{1}$, A Misno BP ${ }^{2}$ \\ Muhamadiyah Islamic College, Singapore ${ }^{1,2,3}$ \\ Institut Agama Islam Sahid, Bogor ${ }^{2}$ \\ \{haiminsg@gmail.com ${ }^{1}, \underline{\text { drmisnomei@inais.ac.id² }}$ \}
}

\begin{abstract}
The obstacles and challenges faced by People With Disabilities (PWDs) or Orang KurangUpaya (OKU). It is not surprising that some survive with a thousand miseries, which leads to mental and emotional stress. It happens in schools, the workplace as well as within the social circle where PWDs encounter acceptance, recognition, and treatment barriers. These issues bring about a severe impact where PWDs deprived of opportunities to enjoy educational, career and societal achievements that could be proud. Not only that, but opportunities to achieve in the religious sector are also lacking. This research presents the opinions and voices of PWDs in relation to their real situation they are experiencing and their hopes that the able-bodied members of the society synergize their efforts to assist them in overcoming the challenges with strong will and aspiration and faith through dakwah management programs under one roof specifically to the visually impaired such as learning the Quran using braille and other Islamic knowledge. Dakwah challenges for PWDs come from internal and external factors. Internal factors being low selfesteem leading to a lack of confidence in executing Islamic values whereas external factors include societal attitude and government policies.
\end{abstract}

Keywords: Orang Kurang Upaya (OKU), People With Disabilities (PWD), Moslem Minority, Islamic Dakwah.

\section{Introduction}

According to the Summary of Singapore Social Statistics 2011, the Muslim population of 14.7\% in 2010[1]. A small number fall into the category of People With Disabilities (PWDs). About information provided in the Annual Report of the Association of Visually Impaired People 2011/2012, the number of Muslim Malay members is 417 persons, which belong to the category of total or partial blindness. In their circumstances, it should be more comfortable to achieve the quality of life, worship practices, and other welfare issues. However, the situation does not make it easier, with small numbers present in the middle of a high tech rich country of Southeast Asia, as reported by BBC News Asia newspaper July 5, 2012.

There was a limitation of opportunities upgrading in the ukhrawi perspective as well as backwardness in duniawi that are already well-known. Thechance to gain a firm religious education is enabling in their journey through life to achieve spiritual emotion, career, and economic status, with self-confidence in positive way.

The background issues conclude the subject will be focusing on how is the dakwah management performed for the Muslim community within a single roof in Singapore.

\section{Method}

The qualitative approach applied in this research. Kirk and Miller[2], qualitative observation involves the measurement of the level of a particular feature, the descriptive characteristics of the data collected, including words, pictures, and not numbers. The type of research represented by the way data is collected. The data collected through questionnaires, interviews, library studies, and observations. Data sources obtained from respondents who would be randomly selected from members of the Singaporean Association of Visually Impaired Students and students with disabilities and others, who attend religious studies programs at two Islamic organizations or organizations directly or in close contact with groups disability; Radin Mas Studies and Religious Body (BAPA) and Bedok Youth Society. 
Data Collection Techniques obtained from those who are related to visually impaired persons through investigations, interviews, and library studies[3]. The purpose is detailing the existing specificity in unique contextual. Researchers also conducted interviews with mosque officials representing the area of the mosque group to identify the mosque's views on the implementation of the program, with a survey as the instruments. The questionnaire divided into two sections, namely A containing information on the respondents' background and $\mathrm{B}$ containing items related to the research question, distributed to selected respondents.

The data obtained is processed, concludes based on the summary data computes the number of answers selected. Further, data analyzed using classification methods as well as the interpretation of whether they are reliable, expected, and also transferable so that a conclusion can be drawn.

\section{Result And Analysis}

The Republic of Singapore located at the edge of the Malay Peninsula bordering to Malaysia, Indonesia, and Brunei. The country is 248 square miles (642 square kilometers). The name "Singapore" derived from the word of Lion ("Lion City"), commonly used since the 14th century. After independence, the island nation became known as the Republic of Singapore. The country is a multi-ethnic country consisting of four major ethnic groups, namely, Malays, Chinese, Indians, and others like Serani.

Its population has reached 5.2 million, of which 3.7 million are Singaporeans, and the remaining 532 thousand are permanent residents[4]. The Chinese make up about 75 percent of the community, while the Malays make up 14 percent, about 7 percent of the Indians, and the rest about 1 percent belong to other ethnic groups like Serani and others. It makes it a nation of many races, languages, and religions. Malay is the national language while the official language is English, which is also the language of administration and the first language of school. Malay, Mandarin, and Tamil are the mother tongue or second language.

Interviews with respondents indicate that there is no denying that their need for knowledge in ukhrawi has because most of them know where and who is managing it. They are also aware of the obligation that imposed on them as Muslims and feel that the administration of the dakwah is not something to be taken lightly.

However, the answers to the third and fourth questions indicate a complaint from this group of people who feel dissatisfied with the quality of the program that has held so far and welcome change that will support their passion and confidence to move forward and achieve the best of humanity Normal.

Table 1. Tabulate Analysis of Dakwahunder One Roof

\begin{tabular}{|c|c|c|c|}
\hline No & Question on Dakwah Arrangement under one roof & Numbers & $\%$ \\
\hline \multirow[t]{3}{*}{1} & Do you agree with this program/idea? & & \\
\hline & Agree & 31 & 100 \\
\hline & Not Agree & 0 & 0 \\
\hline \multirow[t]{3}{*}{2} & $\begin{array}{l}\text { Will your confidence support in change the fate/opinionof the } \\
\text { society to PWD? }\end{array}$ & & \\
\hline & Agree & 30 & 97 \\
\hline & Not Agree & 1 & 3 \\
\hline \multirow[t]{3}{*}{3} & $\begin{array}{l}\text { Lessoning on knowledgeand searching will more attractive } \\
\text { dan interesting. }\end{array}$ & & \\
\hline & Agree & 30 & 97 \\
\hline & Not Agree & 1 & 3 \\
\hline \multirow[t]{3}{*}{4} & Do you feel a new chance willopen to the PWD? & & \\
\hline & Agree & 29 & 94 \\
\hline & Not Agree & 2 & 6 \\
\hline \multirow[t]{3}{*}{5} & Knowledge of PWD will continue to improve. & & \\
\hline & Agree & 31 & 100 \\
\hline & Not Agree & 0 & 0 \\
\hline
\end{tabular}

On the next tabulation, researchers feel strong support and high expectations of the PWDs, the plans, and continuing stage that will surely bring the benefits and long-term support of achieving better standards and quality of life and perfect.

Most of them agree that the significant change they can enjoy is;

1. The attention of philanthropic, scholars, and volunteers to come together to harness the energy of creating a more open and open path for them;

2. New opportunities that will give them a sense of purpose in life; 
3. Injectable knowledge, skills, and expertise that can help them be competitive live independently, be positive in the face of life's obstacles and challenges, and have a helping spirit that is needed most from them.

The results show a significant number of respondents feel that pre-existing program management is available, not for a small amount of them. All respondents agreed that the dakwah program was held under one roof for the disabled in anticipation of change and improvement. All of them are confident that this will come true and raise the level of knowledge of this group to the level of ordinary human achievement.

Feedback from the survey also indicates that a significant number of respondents are still dissatisfied with current management. It will undoubtedly undermine the belief that the PWD community can even thrive in the field of dakwah, as it does not achieve the expected benefits. Also, the dakwah program structure and management as they believe it can open up new opportunities for the PWD community to improve their standard of living duniawi and ukhrawi.

Based on the profile and feedback received, this study has been able to get an accurate picture of the situation of the disabled in Singapore, such as social status, job opportunities, education status, and religious background of this group. The following are some of the respondents' responses to their understanding of dakwah management:

a. Religious studies, the Qur'an and etcetera;

b. Enhancement of knowledge that can help to be calm, patient and persevering in difficult times and also be thankful;

c. Knowledge-based classes/programs for PWD that help build self-esteem through religious education that include moral and akhlaq education.

d. Upgrading of knowledge improves living in the world and the hereafter.

e. Opportunities to demand and enhance the spiritual experience to build self-confidence and contribute to society and to fear Allah.

f. Learn and teach in disseminating religion to the community.

g. It is an institution where the PWD class is given religious education so that it can fulfill its obligations and highlight Islamic teachings to the best of their ability.

There is no doubt that efforts in the management of dakwah are to be seen with this group, but, based on the input of the respondents, there is much that needs to do for this real effort to be carried out to the best of our ability. Based on this fact, the study also successfully describes the attention of dakwah management, which expected of the visually impaired community as well as others. Here are some of the respondents' responses:

a. Dawah management should come from someone experienced and qualified. The needs of the PWD in obtaining religious education are recognized, and efforts are ongoing to find the right teacher.

b. The scholars and volunteers understand how to manage the dakwah management program for the PWD group to encourage the participants.

c. The management should combine the ordinary person and the PWD. It will enable the PWD function as part of society and not feel excluded. With this, the community will better understand how PWDhaving knowledge or education with more effective assistance.

d. Consolidate existing PWD goals and identify particular needs. The specialized knowledge needs in handling the program, as each PWD has its own specific needs and requirements.

e. Convincing and proper management so that enabling PWDto to achieve their goals of attaining the knowledge to improve the standard of living covered by social and financial limitations.

A mosque in southeastern Singapore has identified as the place of implementation dakwah management program for suitable Muslim communities in Singapore. Selections are made based on the following listed items: 
Table 2. Selection Location Criteria for the Program

\begin{tabular}{lcc}
\hline \multicolumn{1}{c}{ Description } & \multicolumn{1}{c}{ Advantages } \\
\hline Location & Strategic location in the north area. \\
\hline Easiest and Surrounding & Close to inter-mode of Bus and MRT with low traffic situation \\
\hline Building Shape & - & Less staircase. \\
& - The classroom located on the first floor for the \\
& - The abolition and toilet on the first floor \\
& - & Management office on the first floor as well. \\
\end{tabular}

The mosque's readiness to respond to the challenge of legitimizing dakwah work under one roof is expected to increase the people's trust and confidence in the mosque's versatile in addressing community issues, including those with disabilities. The next step is to adopt the right, efficient, and effective implementation of the concepts to achieve the long-term benefits of the parties concern. As mentioned earlier, work practices that consolidated and co-ordinated need to be taken into account and implemented make the journey of the program will remain stable and guided. It means that integrated co-operation is essential to all parties involved in the implementation of this program.

If the programmers and managers have the mental, physical, experience, and knowledge to implement the program, the disabled will need equipment or tools as well as other specialties such as the environment for the program execution. Among the specific requirements that will help facilitate the implementation of this program are;

1. PWD friendly place; the area of dakwah administration is being modified to meet the needs of the visually impaired, such as:

a. Routes to rough-edged places of study in specific locations as a waymarker, especially to areas of prayer, prayer halls, and classrooms.

b. Roadblocks and signage provided along the route of the preceding or other relevant or frequently visited areas.

c. Notifications in Braille letters expected spaces such as button-lifts, etc.

d. Hand-written signboards for the blind.

2. Program material or materials and specialized tools.Illustrations of some tools and a brief introduction to the Braille writing system included in the appendix.

a. The Qur'an, books, and others shall make in capitalized and Braille versions.

b. The materials shall make in the form of compact discs and etcetera.

c. Braille typewriter.

The above facilities will not only facilitate the smooth running of the program but also create a sense of safety and security to stay. While the use of tools and learning methods appropriate to this group of people will undoubtedly inspire confidence and attract even more participants, including the public benefit from this management program. For the ordinary people who visit this place like pilgrims and scholars and others, of course, it will be amazed and grateful to discover that Islam is for everyone and allow the joy of living religious life under one roof in control of the heart. Feelings of demanding knowledge and maintaining fellowship. These are some of the messages of a scholar; Imam Shafi'e quoted from a novel of Islamic history[5]:

a. The heart is the king within. So straighten up and correct it so that your empire stands upright on al-Haq that is not joined by any band of comedians.

b. It has acquired much knowledge as possible because it protects you and excels you in the world and the hereafter. It is also the practice of prophets, apostles, and saints.

c. Whoever makes friends (ukhuwah) and brings them to life, they have many benefits.

\section{Trained Human Resources}

Another essential logistical requirement is human resources, who are involved in this program should be trained to carry out a dakwah management program for the disabled. Starting from the stubbornness and perseverance of facing and addressing future challenges. The purpose of the service is to focus on 
promoting self-confidence and self-reliance. A strong belief in yourself to boldly try something new can be one of the participants' self-improvement strategies.

As has been pointed out in the beginning, the visually impaired comprises a wide variety of subjects such as the half-blind, the blind, the blind, and the deaf, the blind with limited mental intelligence. Managers need to take these variables into account and adjust the program structure and curriculum according to their limitations. A notable difference between the visually impaired is that they prefer the Auditory learning style of listening and Kinesthetic learning, moving, working, and touching[6]. The following are some steps you can take to achieve the goals you set out:

a. Involve those who have the potential for representation in assimilation and integration with the society through organized community activities and dakwah;

b. Provide those who are qualified to represent this group within the mosque committee or internal working committee;

c. Establish a memorandum of cooperation with educational centers, madrasahs, or other dakwah institutions in the field of public service programs or to prepare those who are capable of contributing to the community.

To realizing, according to the Minister responsible for Islamic Affairs, Dr. Yaacob Ibrahim, quoted in the Daily News newspaper as of August 31,2012, also needs to continue to be involved in raising interest and encouraging their children to love knowledge while at the same time fostering closer family ties. It is not surprising that the following atmosphere created by the efforts of dedicated and committed human resources;

a. The classroom situation can be well managed and controlled, with all the students present entirely focused on the lesson.

b. The student's commitment will be thick and vibrant just for the sake of religious knowledge.

c. The level of achievement in the study will change over time as the students progress.

d. The level of morality, personality, and behaviors of the students will be in line with what they have learned in the program.

4. Structure and curriculum of accredited programs;

Implementation of the administration of the dakwah itself includes the following;

a. Interactive and customized learning models based on the type or level of vision problems encountered, to stimulate motivation;

b. The aim of the study focused on the mastery of the Braille writing system and its ability to read in English, Malay, Arabic (Quranic language), and even if possible, foreign languages such as Mandarin. At the same time, foster a love of reading and a love of knowledge. Examples of Braille texts featuring Surah Al-Fatihah and its translation in Malay included.

c. The division of students according to their disability and ability

5. Management, Administration and Finance

The implementation of these three things can be done under the principles of consolidation and coordination as well as through planning, organizing, actuating, and control, namely POAC. Helping the disabled through the contribution of specialized expertise. In particular, members of the mosque committee selected to carry out the program can assist in educating the community about the existence and purpose of the program. Also, it makes the program a "niche" or exclusive activity only in the mosque. Standard logistics requirements can also be submitted to the mosque, such as a desk and soft drinks, as well as other simple logistics requirements.

The Association of Visually Impaired People of Singapore (SAVH) can cooperate by informing its Muslim Malay/ members of the existence of programs specifically designed for them to meet the spiritual needs not provided by the association. Meanwhile, Radin Mas's Studies and Religious Body (BAPA) provides trained professionals to organize structured or modular programs for their targets. Also, external lecturers/speakers may also be invited to make this program a success. The Bedok Youth Association can help provide goods, experienced volunteers to guide the target to move independently and comfortably throughout the program, while also teaching them other useful skills.

A committee formed, and all of the participating bodies must present one or more representatives to ensure that their contribution of expertise is well managed and presented to the other representatives. After the agreement signed by these bodies, the funds and financial issues to cover the costs of maintaining the 
program should give attention. Energy mobilization can also be done through fundraising partnerships through fundraising projects. Proceeds from ongoing projects can expect from the sale of gift books, program fees and regular donations from corporate bodies and government social departments.

All of these elements need to be involved in the POAC process, where planning consists of the creation of goals, visions, missions, and work programs that implemented in the form of realistic goals and targets, activity schedules, and objective budgets. It needs to carefully plan for example in the division of labor and labor supply. When ready, they are mobilized so that they can lead, motivated and skilled, followed by control in terms of performance and achievement[7].

\section{Conclusion}

Based on the feedback received, the researchers believe that stepping up an excellent and high-quality roofing program under one roof can serve as a bridge to the impact and the convincing ambitions of the PWD community in Singapore.

The administration of dakwah is essential and needs to be a part of people's lives, especially the visually impaired and those in general. They should be able to enjoy the results of the purely objective, practical, and dakwah management and teaching of their mission through detailed descriptions. The attention given to their circumstances and needs from the standpoint of dakwah and community management so that there is an alternative path for them to explore their capabilities and make contributions.To the future development of ourselves, our nation and our society.

\section{References}

[1] Strategic Planning Research and Development Division, "Singapore Social Statistics in Brief," Singapore, 2011.

[2] J. Kirk and M. L. Miller, Qualitative Research Methods: Reliability and validity in qualitative research. Newbury Park, CA: SAGE Publications, Inc., 1986.

[3] L. J. Moleong, Metodologi Penelitian Kualitatif. Bandung: Remaja Rosda Karya., 2007.

[4] Enabling Masterplan Steering Committee, "Available Data on Disability in Key Demographic Indicators, (1970 - 2011)," in Enabling Masterplan 2007 - 2011, Singapore: Enabling Masterplan Steering Committee, 2011.

[5] A. L. Talip, Novel Sejarah Islam, Imam Syafie Pejuang Kebenaran. Selangor, Malaysia: PTS Litera Utama Sdn. Bhd., 2010.

[6] H. DePorter, Bobbi dan Mike, Quantum Learning Membiasakan Belajar Nyaman dan Menyenangkan. New York: Dell Publishing, 1992.

[7] M. Ruswandi and Rama Adeyasa, Manajemen Mentoring. Bandung: Syaamil., 2007. 